\title{
AN INVESTIGATION OF ONLINE NEWS CONSUMPTION BEHAVIOUR OF A MALAYSIAN HIGHER EDUCATION INSTITUTION: A CASE STUDY OF SOUTHERN UNIVERSITY COLLEGE
}

\author{
Hup Xiao Hui* and Ker Yuek Li \\ Southern University College, Malaysia
}

\begin{abstract}
The Internet and new technologies have created new versions of news reporting, and they have changed the news consumption behavior of people around the world. The online news consumption among adolescents nowadays may differ from the older news consumers because of the accessibility of the Internet and other news sources provided in their growing environment. This study examines the online news consumption behavior among the students in private university college by applying uses and gratifications theory. There were 341 respondents engaged in this study. The Pearson correlation coefficient and one-way ANOVA analysis are applied in data analysis to identify the relation of interactivity, demassification, and asynchrony to the online news consumption behavior. The finding reveals there is a significant difference between the attribute of interactivity, demassification and asynchrony to online news consumption behavior. These attributes have led the respondents toward online news use to fulfil their cognitive needs, social integrative needs and affective needs. Meanwhile, news from Facebook specifically lifestyle news is generally consumed by university students today.
\end{abstract}

Keywords: online news consumption, higher education students, uses and gratifications theory

\section{Introduction}

Internet is a global network that connects people all around the world. This means that two or more people are able to communicate with each other when connected to the Internet, even deal with ideas and events outside their home (Sullivan, 2013). It encouraged the growth of social networking sites, blogs and so on, which helped increase the popularity of the Internet (Dominick, 2010). The Internet begins as the supplement of traditional media's surveillance function. According to Qayyum et al. (2013), internet and the subsequent development of new online media serves as a new model of news that allows people to create articles or provide more detailed information compared to traditional media and spread it to all who are interested. In addition, its interpretation function also allows users to put in their opinion on the news topics or even controversial issues (Dominick, 2010). Internet also provides the check and balance to the traditional news media and make the traditional media reporting more transparent (Dominick, 2010).

However, the issues of credibility of online news sources is one of the factor that affect students have more confidence in traditional news sources. (Qayyum, et al., 2010; Saodah Wok et al., 2011). Nevertheless, online news sources serve as an extension of news sources when students need more details about some story that was produced by the established news organizations, such as a traditional television website and newspaper outlets (Antunovic, et al., 2016).

Although the declination of newspaper readership among young adults are shown in several studies (Huang, 2009; Graybeal, 2011; David et al. ,2017). Huang (2009) indicates that the news media failed to address youth's news consumption behavior. First, there was the time constraint; students had a limited time for news consumption as they were busy on their schoolwork and sometimes on their jobs. Second, students do not like trivial and sensationalized news content such as gossip of other (Huang, 2009), they prefer or are concerned about topics that influence their life (Qayyum et al., 2010). Third, people felt bored with the dated delivery 
approach and lack of innovation in the format of broadcast news (Huang, 2009). Young adults in Australia are inclined to be more attracted and to trust print newspapers more than online news (Qayyum, et.al., 2010). However, in the Malaysian context, TV news consumption rate is higher than newspapers and Internet news consumption (Wok, et al, 2011). Media Insight Project (2014) has found that American adolescents are active news consumers, and they belong to the category which is less attentive to daily news, but aggressive to breaking news. Comparing to Americans, Malaysian adolescents are keen on entertainment news, followed by crime news and news of events taking place in their community (Freeman, 2013). Huang (2009) states that college students were most interested in the sport news, and then followed by world, local and entertainment news. Hard news and entertainment news were the most popular among students and yet economic and political news seemed to be unattractive among young people from the age 16 to 18 (Raeymaeckers, 2004).

Therefore, it is interesting to investigate on online news consumption behavior among Malaysian private university college students, to know what their motivation is and the pattern of online news consumption besides the credibility of the Internet. Furthermore, to encourage young people to read the news which is considered as an important thing in our life. Besides, this study provides a guideline for news agencies upon disseminating information and news to target audiences. By understanding the preference and need of the audience, the news agency can serve the audience in a better way. This way, the news can be spread more widely and reach a larger audience. Accordingly, our research question is as follows:

- Research Question: Does the attribute of interactivity, demassification, and asynchrony of online media correlates to the online news consumption behaviour among Malaysian private university college students?

\section{Literature Review}

The rise of network brings convenience to society. People nowadays tend to get information online rather than offline (Antunovic, et al, 2016). A report from Malaysian Communications and Multimedia Commission (MCMC) in 2015 states that $90 \%$ of Malaysia's Internet users regard the internet as a source of information and that according to $86.9 \%$ of the internet users, social media has become the main source of information. Huang (2009) research has found that nowadays students are leading fast-paced lives juggling between education, jobs, social networking, etc. Most of the students put the needs of news consumption at a lower priority, and engage in their highly prioritized activities, such as communicating with friends. The new media - Internet has fulfilled the wide range of gratifications for college student. That is why the needs of consuming news online have only occupied a small part of their gratification needs (Huang, 2009).

\section{Uses and Gratification theory}

Uses and gratification theory is implemented in this study to assess the online news consumption behavior. The theory is grounded in the idea that users are active consumers in selecting the media and information sources according to their needs and they want to reach their personal needs (Rubin, 2009). The core value of uses and gratification theory is satisfaction. It explained that audience has a specific "need" of individuals; they have specific needs and are motivated to get "satisfied" in the process of media contacts. However, there is a revival of theory since the development of new media--Internet applications and digital products, especially the attribute of interactivity, demassification, and asynchrony (Ruggiero, 2000; Baran and Davis, 2012). The interactivity refers to the direct interactive with each other (Williams et al., 1988); Demassification is defined as people are able to select news topics of interest from a wide menu (Ruggiero, 2000). According to Ruggiero (2000), asynchrony is the concept that messages may be staggered in time. In order words, it provides the ability to send or to receive messages by their own convenience (Chamberlain, 1994). The three attributes (include 
interactivity, demassification, and asynchrony) are adopted in this study as they are most relevant to examine the news consumption behavior in using the new media.

\section{Theoretical Framework}

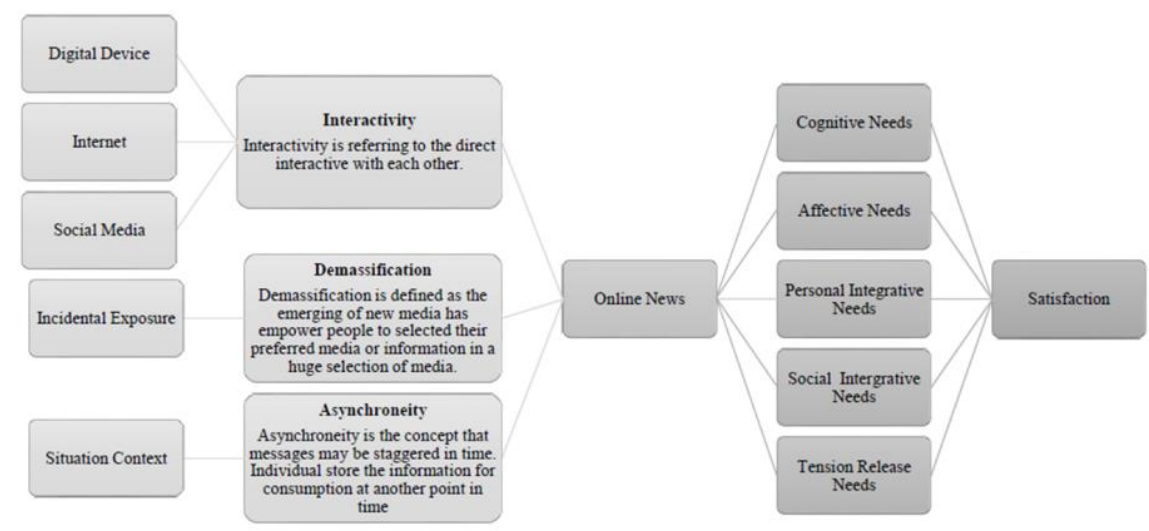

Figure 1 Theoretical framework.

Figure 1 is the theoretical framework in this study. It is modified from the uses and gratifications theory especially the satisfaction of needs (including cognitive needs, affective needs, personal integrative needs, social integrative needs, and tension release needs) and the attributes of online news website including (interactivity, demassification, asynchrony) to examine the online news consumption behavior of Malaysian university college students.

Hypothesis 1: There is no significant difference between the attribute of interactivity and online news consumption behaviours among students in Southern University College.

Hypothesis 2: There is no significant difference between the attribute of demassification and online news consumption behaviours among students in Southern University College.

Hypothesis 3: There is no significant difference between the attribute of asynchrony and online news consumption behaviours among students in Southern University College.

\section{Methods}

The quantitative research method is employed in this study because it enables the researcher to generalize the behavior of a group of students (Allen et al., 2009). Southern University College is chosen for this study as a sampling because of its location proximity and the diversification of their programs offered. An online survey is applied for data collection, since it is free from the restriction of cost and time. There are 341 students from Southern University College involve in the survey. Descriptive analysis, Pearson Correlation Coefficient, and one-way ANOVA are the methods for data analysis. Person Correlation Coefficient analysis is implemented to examine the relation between interactivity, demassification, and asynchrony to online news consumption behavior. Meanwhile, one-way ANOVA is applied to test the significant difference of faculty and school, and hours spending of online news to the satisfaction with the interaction, demassification, and asynchronies function of online news respectively. 


\section{Results}

\section{Pearson Correlation Coefficient}

\section{Interactivity}

Table 1: Effectiveness of exchanging the ideas with other correlates to the attribute of interactivity

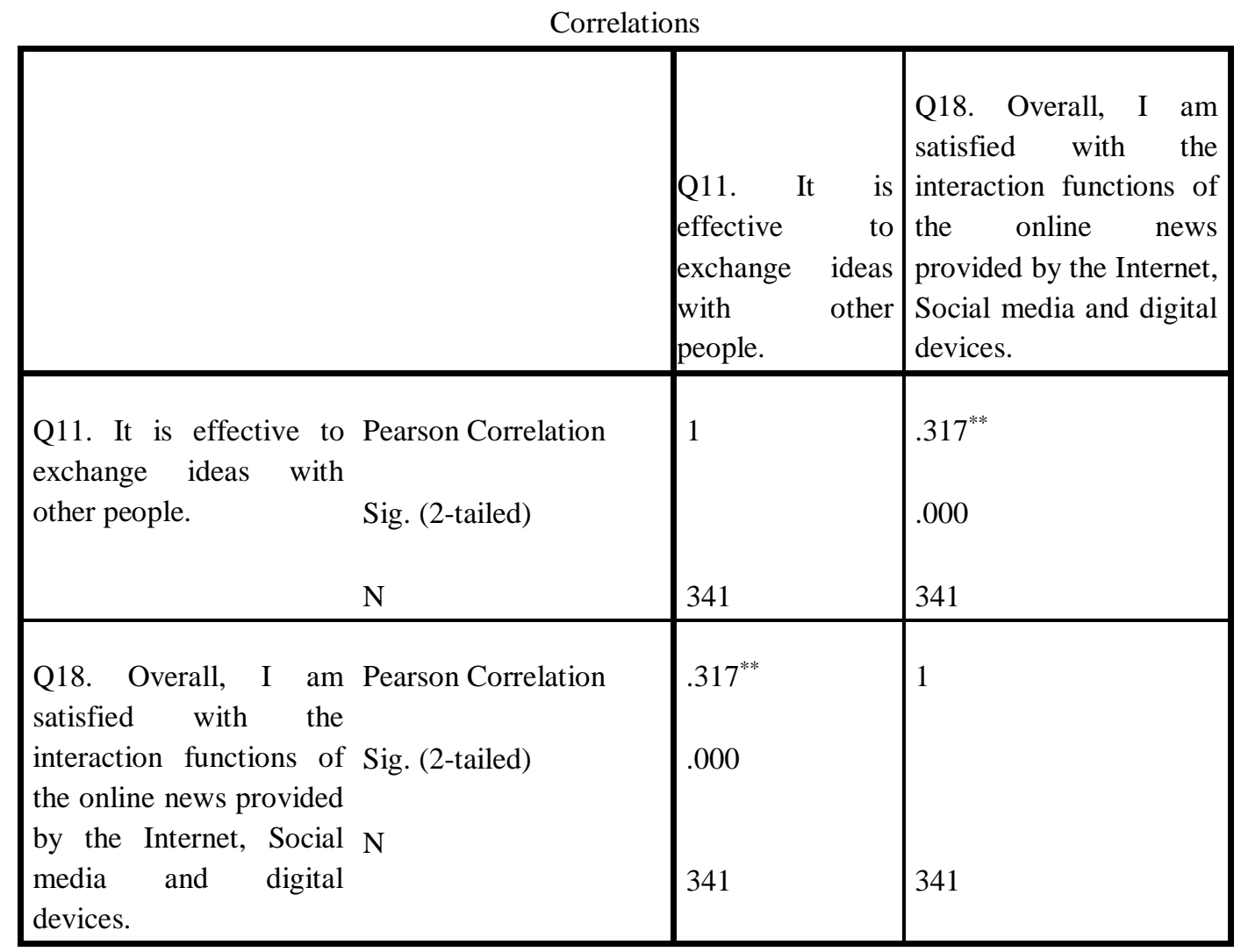

**. Correlation is significant at the 0.01 level (2-tailed).

Table 1 indicates that the p-value is 0.00 which means there is a statistically significant correlation between the items question 11 and question 18. However, the correlation coefficient value between question 11 and question 18 is 0.317 . This means that the question 11 "effective to exchange ideas with other people" has a moderate effect on question 18" satisfied with the interaction functions of the online news".

\section{Demassification}

Table 2: Ease and flexibility to use correlates to the attribute of demassification

Correlations

Q21. It's easy and flexible to use.
Q26. Overall, I am satisfied with the online news provideing a wide range of information. 


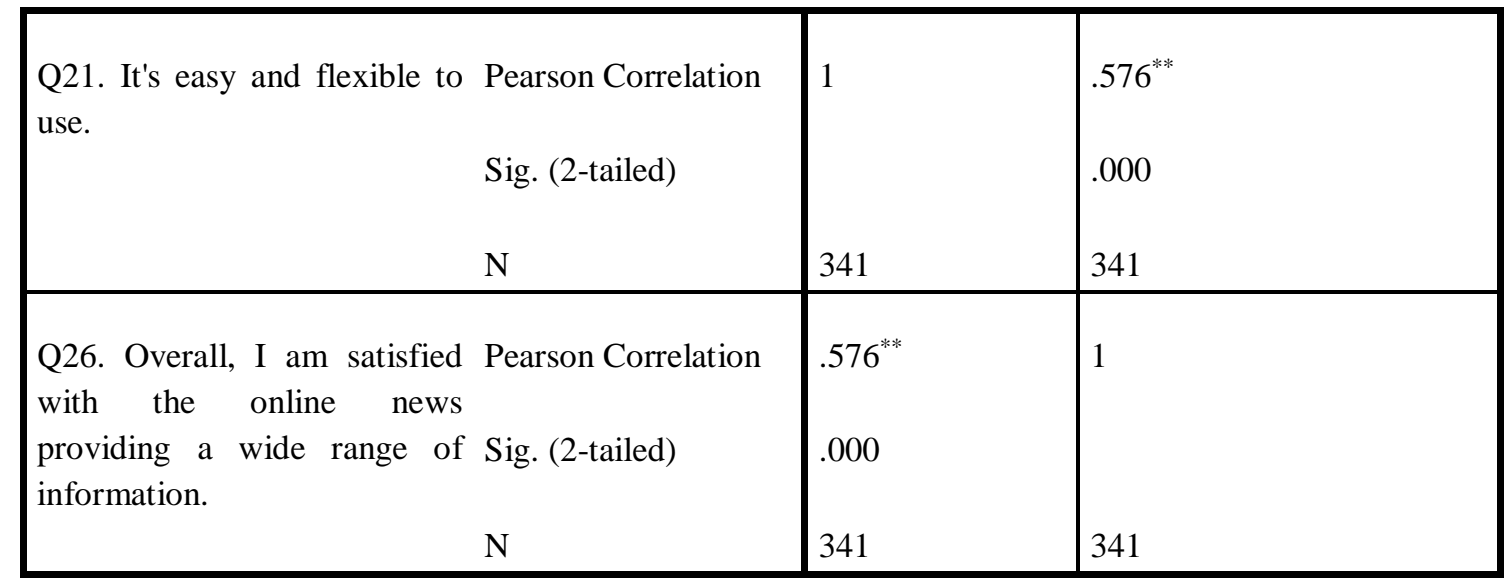

**. Correlation is significant at the 0.01 level (2-tailed).

Table 2 indicates that the p-value is 0.00 which means there is a statistically significant correlation between the items question 21 and question 26. However, the correlation coefficient value between question 21 and question 26 is 0.576 . This means that the question 21 "ease and flexibility to use" has a strong effect on question 26 "satisfied with the online news providing a wide range of information".

\section{Asynchrony}

Table 3: Timeliness news from all around the world correlates to the attribute of asynchrony

\begin{tabular}{|c|c|c|c|}
\hline \multicolumn{4}{|c|}{ Correlations } \\
\hline & & $\begin{array}{l}\text { Q29. I am able to } \\
\text { obtain timeliness } \\
\text { news from all } \\
\text { around the world. }\end{array}$ & $\begin{array}{l}\text { Q33. Overall, I am } \\
\text { satisfied without the } \\
\text { geographical and time } \\
\text { restriction functions of } \\
\text { online news }\end{array}$ \\
\hline \multirow[t]{3}{*}{$\begin{array}{l}\text { Q29. I am able to obtain timeliness news } \\
\text { from all around the world. }\end{array}$} & $\begin{array}{l}\text { Pearson } \\
\text { Correlatio } \\
\mathrm{n}\end{array}$ & 1 & $.595^{* *}$ \\
\hline & $\begin{array}{l}\text { Sig. } \\
\text { (2-tailed) }\end{array}$ & & .000 \\
\hline & $\mathrm{N}$ & 341 & 341 \\
\hline \multirow[t]{3}{*}{$\begin{array}{l}\text { Q33. Overall, I am satisfied without the } \\
\text { geographical and time restriction functions } \\
\text { of online news. }\end{array}$} & $\begin{array}{l}\text { Pearson } \\
\text { Correlatio } \\
\mathrm{n}\end{array}$ & $.595^{* *}$ & 1 \\
\hline & $\begin{array}{l}\text { Sig. } \\
\text { tailed })\end{array}$ & .000 & \\
\hline & $\mathrm{N}$ & 341 & 341 \\
\hline
\end{tabular}


**. Correlation is significant at the 0.01 level (2-tailed).

Table 3 indicates that the p-value is 0.00 which means there is a statistically significant correlation between the items question 29 and question 33. However, the correlation coefficient value between question 29 and question 33 is 0.595 . This means that the question 29 "able to obtain timeliness news from all around the world" has a strong effect on question 33 "satisfied without the geographical and time restriction functions of online news".

\section{Result of One Way ANOVA Analysis}

Table 4 Difference of faculty and interactivity function

Dependent Variable: Faculty and School

\begin{tabular}{|c|c|c|c|c|c|}
\hline Source & $\begin{array}{c}\text { Type III Sum of } \\
\text { Squares }\end{array}$ & df & Mean Square & $\mathrm{F}$ & Sig. \\
\hline Corrected Model & $2.235^{\mathrm{a}}$ & 4 & .559 & .133 & .970 \\
\hline Intercept & 869.616 & 1 & 869.616 & 206.559 & .000 \\
\hline $\begin{array}{l}\text { Overall, I am satisfied with } \\
\text { the interaction functions of } \\
\text { the online news provided by } \\
\text { the Internet, Social media and } \\
\text { digital devices. }\end{array}$ & 2.235 & 4 & .559 & .133 & .970 \\
\hline Error & 1414.563 & 336 & 4.210 & & \\
\hline Total & 4069.000 & 341 & & & \\
\hline Corrected Total & 1416.798 & 340 & & & \\
\hline
\end{tabular}

a. R Squared $=.002($ Adjusted R Squared $=-.010)$

Table 4 shows the output of ANOVA analysis between question 3 faculty and school on question 18 "satisfied with the interaction functions of the online news" in the interactivity section. It indicates that the p-value is 0.97 which is above 0.05 . Therefore, there is no significant difference between faculty and school and satisfaction of interactivity. 
Table 5 Hours spending on online news per day and interactivity function

Dependent Variable: How many hours do you spend on online news per day?

\begin{tabular}{|l|c|c|c|c|c|}
\hline Source & $\begin{array}{c}\text { Type III Sum of } \\
\text { Squares }\end{array}$ & df & Mean Square & F & Sig. \\
\hline Corrected Model & $14.920^{\mathrm{a}}$ & 4 & 3.730 & 2.885 & .023 \\
Intercept & 504.207 & 1 & 504.207 & 390.005 & .000 \\
$\begin{array}{l}\text { Overall, I am satisfied with } \\
\text { the interactive functions of } \\
\text { the online news provided by } \\
\text { the Internet, Social media and } \\
\text { digital devices. }\end{array}$ & 14.920 & 4 & 3.730 & 2.885 & .023 \\
Error & 434.388 & 336 & 1.293 & & \\
\hline Total & 2170.000 & 341 & & & \\
\hline Corrected Total & 449.308 & 340 & & & \\
\hline
\end{tabular}

a. $\mathrm{R}$ Squared $=.033($ Adjusted R Squared $=.022)$

Table 6 shows the output of ANOVA analysis between question 5 " How many hours do you spend on online news per day " and question 18 "satisfied with the interactive functions of the online news" in the interactivity section. The results show that the p-value is 0.023 which is below 0.05 . This means that there is a significant difference between online news time spending and the interactive functions provided by the Internet, Social media and digital devices.

\section{Discussion}

The finding indicates that there is significant difference between interactivity and online news consumption behavior. It is corresponding to the result finding of Ko et al. (2005) which states "consumers who have high convenience and social-interaction motivations are more likely to engage in human-human interaction on a Web site". People use a news medium's perceived worthwhileness includes subjectively experienced material, situational and functional circumstance time avails that characterizes the medium's practice of use. There are five factors: (1) time available; (2) the affordance of "public connection"; (3) price; (4) normative constraints; and (5) participatory affordances (Schrøder \& Steeg Larsen, 2010). Among the factors provided, the affordance of "public connection" and participatory affordances is greatly related to the hypothesis in this study.

"Public connection" is a concept that has to do with the ability of the media to meet the needs of the individual through its content, in order to serve as a citizen of the democratic order, as well as a community member in the broadest possible sense (Couldry et al., 2010). Together with participatory affordances, it is important to the individual to engage in the communication process, as well as to be an active role in conversation, and even to be able communicate sensibly with significant others in one's close networks (Raeymaeckers, 2004). Therefore, 
the function of connection motivates university students toward online news use in order to engage in the communication process.

In fact, the present finding is consistent with prior researches (Huang, 2009; Raeymaeckers, 2004), the respondents need to have the knowledge of what is going on around the world in order to benefit from the knowledge that can be gained in conversations with others. At the same time, two of the five gratifications given by Katz et al. (1973): cognitive needs and social integrative needs can also be confirmed in this study. The person who wants or needs to gain knowledge, he or she might be motivated by online news. The function of interactivity seems to fulfil their needs of interactivity. However, the result did not appear as strongly as the others.

Meanwhile, the correlation coefficient results reveal that there is significant difference between demassification and online news consumption behaviours. The finding of perceive ease and flexibility to use is consistent with the research study done by Sledgianowski \& Kulviwat (2009), they found that perceive ease of use has positive and significant effects on the intention to use social networking sites. On the other hand, people are likely to continue using websites in the future as long as they can easily communicate with others (Wu, et al., 2008), as well as perceive ease of use in technology system (Davis, Bagozzi, \& Warshaw, 1989). For this reason, higher education students will choose to go toward online news use if they perceive the online news as ease of use.

Furthermore, price also is an indicator affecting online news consumption behavior. As technological capability of the Internet could decrease costs (Chan-Olmsted et al., 2013). In the research of Chyi \& Yang (2009), disclose income contrasts with online news consumption behavior. People tend to spend for expensive items when their income rises. However, with the rise of incomes, consumption of online news decreases. Thus, they demonstrate that online news is inferior goods. When people choose to go toward online news use, it might be because of the decrease of incomes. With the result showing that the respondents agree and are satisfied with "saving money in getting the news", it is possible to say that they have low incomes or even no income at all, so online news become the first option among several news sources.

Incidental exposure is a process of consuming news in a way that without the generally active news consumption process, news can also occur in unintended ways, such as people often reading newspapers for other non-news related content (e.g. recipe). The results in this study show that it is consistent with the study of Antunovic et al. (2016) stating that young people usually receive news intentionally. With the research of Yadamsuren \& Erdelez in 2011, they found that incidental exposure has become the typical way that people nowadays get news online. There is an increase in incidental exposure to online news (David et al., 2017). Hence, many respondents in the research of Yadamsuren \& Erdelez in 2010, have positive feelings toward the incidental exposure to online news. They described the feeling as "fun", "exiting", etc. Therefore, the respondents in this study can be considered enjoying the incidental exposure to online news but it did not appear as strongly as "ease and flexibility to use" and "saves money to get news". It is necessary to do further research on incidental stage, in order to deeply understand the reason behind.

Adolescents are able to select the news topics they want from the wide range of news provided. Moreover, they are able to save money to explore news as much as possible without charge. Meanwhile, they also can enjoy the incidental way in exposure news without searching, since there is wide range of menu, therefore, they do not need to decide what news to consume in daily routine, unless there is some specific news they want to know about. Demassification function provided by the online news seems to have fulfilled the adolescents' needs of ease and flexibility to use, reducing the burden on economic and also the needs to explore news in incidental ways. New media such as the Internet allows users to access and select information according to their needs in this huge selection of media, when previously people had to enjoy a mass media item with others (Chamberlain, 1994; Kuehn, 1994; Ruggiero, 2000). Thus, these characteristics acquired by the adolescents do not belong to the five needs (including cognitive needs, affective needs, personal integrative needs, social integrative needs, 
and tension release needs), but this can prove that those characteristics gradually formed the audience's behaviors.

The correlation coefficient results state that there is no significant difference between asynchrony and online news consumption behaviours. The result of convenience is consistent with the research study of Salwen et al. (2005), there are several reasons for using online news, and convenience became one of the main reasons for the respondents to use online news. At the same time, the result also consistent to the definition of Palfrey \& Gasser (2011) to the state a person born after 1980s is a digital native. They are the category who rely on the Internet for all day activity, including news consumption, and even engage more with the material than those who are used the traditional news formats. It is possible to say that because most of the daily activities can be carried out on the Internet, adolescents feel that it is very convenient, this is why they choose the online news, but also because the online news meet their needs, so they are satisfied with it and even tend to continue to use it in the future.

As for the significant effect of searchability to the satisfied without the geographical and time restriction function of online news. In the same way, online news allows people to retrieve information when they need. It is consistent with the Chan et al. (2013) study, the resultant Cronbach's alphas show that technology advantages are reliable, which include customization (i.e., interactivity and personalization), immediacy (i.e., wherever and whenever news consumption), and multiplicity (i.e., multimedia/links/searchability formats). Lee \& Ma (2012) argue that social media can also serve as the potential retrieval for users in the future when information seeking needs to arise since the news stories can be stored in an online profile as a private collection.

Besides that, timeliness also has significant effect on the satisfied without the geographical and time restriction function of online news. Timeliness is one of the core elements that characterize news value. However, the emerging of new media (i.e. Internet) has put an additional premium on timeliness comparing to traditional media (Dominick, 2013). Therefore, people need to know what is going on around the world on time, there is no doubt that adolescents are satisfied without the geographical and time restriction function of online news.

The attribute of asynchrony in online media provides the ability to send or to receive a message by its own convenience (Chamberlain, 1994). In this section, the result revealed adolescents read online news in order to get news anytime (convenience), to search old news (searchability), and even to get current news (timeliness). Hence, two of the five needs given by Katz et al. (1973): cognitive needs and affective needs can also be confirmed in this study. The respondents in this study need to gain knowledge and information, then they go online for searching old or current news, which fulfils their cognitive needs. In addition, they also benefit from convenience in getting news or information, which has fulfilled their affective needs. Overall, the results imply that the attribute of asynchrony of online news is more likely to fulfil satisfaction of Malaysia private university college students in consuming the news.

Meanwhile, lifestyle news, entertainment and celebrities' news are the news topics that sparked the most interest among the respondents. For most people, facts are important for politic news or even hard news; when it comes to lifestyle news topics, people do not care about the factual but about the relevant and entertaining topics. In the research of Diddi \& LaRose (2006) indicates that entertainment needs were positive related to individual's Internet news reading. Entertainment content can satisfy individual's needs of escapism, enjoyment, emotional release, and anxiety relief (McQuail, 2010). It is possible to say that respondents in this study are most likely to consume lifestyle news and entertainment and celebrities' news because they need to release their emotions, anxiety or for enjoyment. Moreover, they might lack patience to measure whether the news is flawed with inaccurate information. This can be seen in the result finding which discloses that most of the respondents spent less than 15 minutes reading online news.

Facebook was the most popular social media that respondents used to consume online news. A study from David et al. (2017), found that WhatsApp is generally used by half of the Malaysians for sharing and discussing 
news based on the content privacy setting function. The respondents in this study were the other half of Malaysians that rarely used the messaging application-WhatsApp to share and discuss news but using Facebook. According to the report release from The Statistic Portal (2017), it shows that the ages between 1824 and 25-34 are the largest group of people using Facebook. Hence, it is not surprising that most of the respondents tend to use Facebook for news consumption.

\section{Conclusion}

This study reveals that people are most satisfied without the geographical and time restriction function of online news. In addition, the online news can provide the satisfaction of interaction function, satisfaction of wide range of information provided. These satisfaction reactions reflect a clear relationship between the user's satisfaction, the media, and the characteristic of online news that traditional media did not provided. Therefore, online news of uses and gratifications research must be considered including the characteristics of new media in order to effectively measure the satisfaction of online news. Adolescents nowadays may differ from the older news consumers because of the accessibility of the Internet and other news sources provided in their growing environment. The emerging of new media has created a complex media environment. At least it has created an updated news consumption pattern among the adolescents.

Thus, it is suggested for future research should consider the combination of mix methods, as the methods might be able to gain insight into the news consumptions behavior, since the goal of quantitative research is prediction, generalizability and causality; it enable the researcher to have in-depth understanding of individual perspectives as embedded in their social context contextually based (McGill University, n.d.).

Meanwhile, this study is contributed to journalists and the news organizations in Malaysia by providing a better understanding of the ways that adolescents consume news. Through this, it is hoped journalists and the news organizations will be able to successfully fulfil the demands of adolescents. There is one thing that needs to be considered, besides providing interesting content to keep young readers engaged; we also need to guarantee the news value. It is important to society for media to have the ability to influence people's perception.

\section{References}

Allen, M., Titsworth, S., \& Hunt, S. K. (2009). Quantitative research in communication. Los Angeles: SAGE.

Anderson, M. (2015). Technology device ownership, 2015. Retrieved from Pew Research Center website: http://www.pewinternet.org/2015/10/29/technology-device-ownership-2015/\#fn-14935-1

Antunovic, D., Parsons, P., \& Cooke, T. R. (2016). 'Checking' and googling: Stages of news consumption among young adults. Journalism, 1-17. doi:10.1177/1464884916663625

Baran, S. J., \& Davis, D. K. (2012). Mass communication theory: Foundations, ferment, and future (6th ed.). Cengage Learning.

Beheshti-Kashi, S., \& Makki, B. (2013). Social Media News: Motivation, Purpose and Usage. International Journal of Computer Science and Information Technology, 5(2), 97-105. doi:10.5121/ijcsit.2013.5209

Chamberlain, M. A. (1994). AMERICAN BEHAVIORAL SCIENTIST. New Technologies in Health Communication, 38(2), 271-284. Retrieved from doi/abs/10.1177/0002764294038002008

Chan-Olmsted, S., Rim, H., \& Zerba, A. (2013). Mobile News Adoption among Young Adults. Journalism \& Mass Communication Quarterly, 90(1), 126-147. doi:10.1177/1077699012468742

Chyi, H. I., \& Lee, A. M. (2013). ONLINE NEWS CONSUMPTION. Digital Journalism, 1(2), 194-211. doi:10.1080/21670811.2012.753299

Chyi, H. I., \& Yang, M. J. (2009). Is Online News an Inferior Good? Examining the Economic Nature of Online News among Users. Journalism \& Mass Communication Quarterly, 86(3), 594-612. doi:10.1177/107769900908600309

Couldry, N., Livingstone, S. M., \& Markham, T. (2010). Media consumption and public engagement: Beyond the presumption of attention. Basingstoke: Palgrave Macmillan. 
Davis, F. D., Bagozzi, R. P., \& Warshaw, P. R. (1989). User Acceptance of Computer Technology: A Comparison of Two Theoretical Models. Management Science, 35(8), 982-1003. doi:10.1287/mnsc.35.8.982

David A. L. Levy, Newman, N., Fletcher, R., Kalogeropoulos, A., \& Nielsen, R. K. (2017). Reuters Institute Digital News Report 2017. Retrieved from Reuters Institute for the Study of Journalism website: http://reutersinstitute.politics.ox.ac.uk/sites/default/files/Digital\%20News\%20Report\%202017\%20web_0.pdf

Diddi, A., \& LaRose, R. (2006). Getting Hooked on News: Uses and Gratifications and the Formation of News Habits Among College Students in an Internet Environment. Journal of Broadcasting \& Electronic Media, 50(2), 193-210. doi:10.1207/s15506878jobem5002_2

Dominick, J. R. (2010). The Internet and the World Wide Web. In Dynamics of mass communication: Media in the digital age (10th ed., pp. 274-295). New Delhi: Tata Mcgraw-Hill.

Dominick, J. R. (2013). The dynamics of mass communication: Media in transition (12th ed.). McGraw-Hill.

Graybeal, G. M. (2011). Newspapers Publish Less in Print; Focus on Web to Attract Young Readers. Newspaper Research Journal, 32(1), 90-97.

Griffin, E. A. (2012). Uses and Gratifications. In A first look at communication theory (8th ed., pp. 357-365). New York: McGraw-Hill.

Freeman, K. S. (2013). News Consumption Behavior of Young Adults in Malaysia. International Journal of Social Science and Humanity, 121-124. doi:10.7763/ijssh. 2013.v3.209

Huang, E. (2009). The Causes of Youths' Low News Consumption and Strategies for Making Youths Happy News Consumers. Convergence: The International Journal of Research into New Media Technologies, 15(1), 105-122. doi:10.1177/1354856508097021

Katz, E., Haas, H., \& Gurevitch, M. (1973). On the Use of the Mass Media for Important Things. American Sociological Review, 38(2), 164. doi:10.2307/2094393

Kuehn, S. A. (1994). Computer-mediated communication in instructional settings: A research agenda. Communication Education, 43(2), 171-183. doi:10.1080/03634529409378974

Media Insight Project. (2014, March 17). The Personal News Cycle: How Americans choose to get news. Retrieved from https://www.americanpressinstitute.org/publications/reports/survey-research/personal-newscycle/

Ruggiero, T. E. (2000). Uses and Gratifications Theory in the 21st Century. Mass Communication and Society, 3(1), 3-37. doi:10.1207/s15327825mcs0301_02

Salman, A., Choy, E. A., Mahmud, W. A., \& Latif, R. A. (2013). Tracing the Diffusion of Internet in Malaysia: Then and Now. Asian Social Science, 9(6), 9-15. doi:10.5539/ass. v9n6p9

Salman, A., Ibrahim, F., Hj.Abdullah, M. Y., Mustaffa, N., \& Mahbob, M. H. (2011). The Impact of New Media on Traditional Mainstream Mass Media. The Innovation Journal: The Public Sector Innovation Journal, 16(3), $1-11$.

Salwen, M. B., Garrison, B., \& Driscoll, P. D. (2005). Online news and the public. Retrieved from https://books.google.com.my/books?id=XnORAgAAQBAJ\&pg=PA139\&lpg=PA139\&dq=convenient+in+usin $\mathrm{g}+$ online+news\&source $=\mathrm{bl} \& \mathrm{ots}=\mathrm{c} 5 \mathrm{r} 2 \mathrm{DsD} \_82 \& \mathrm{sig}=\mathrm{CC} \_$Qygh9bvIaeKF524t3oBq1E2k\&hl=en\&sa=X\&redir_es $\mathrm{c}=\mathrm{y} \# \mathrm{v}=$ onepage $\& \mathrm{q}=$ convenient $\% 20 \mathrm{in} \% 20$ using \%20online $\% 20$ news $\& \mathrm{f}=$ false

Sani, M. A. (2005). Media freedom in Malaysia. Journal of Contemporary Asia, 35(3), 341-367. doi: $10.1080 / 00472330580000201$

Schrøder, K. C., $\quad \& \quad$ Steeg Larsen, B. (2010). THE SHIFTING CROSS-MEDIA NEWS LANDSCAPE. Journalism Studies, 11(4), 524-534. doi:10.1080/14616701003638392

Sledgianowski, D., \& Kulviwat, S. (2009). Using Social Network Sites: The Effects of Playfulness, Critical Mass and Trust in a Hedonic Context. Journal of Computer Information Systems, 49(4), 74-83. doi:10.1080/08874417.2009.11645342

Sullivan, J. L. (2013). Media audiences: Effects, users, institutions and power-. Los Angeles: Sage.

Williams, F., Rice, R. E., \& Rogers, E. M. (1988). Distinctions in the Study of New Media. In Research methods and the new media (p. 10). Retrieved from http://www.simonandschuster.com/books/ResearchMethods-and-the-New-Media/Frederick-Williams/9780029353318

Yadamsuren, B., \& Erdelez, S. (2010). Incidental exposure to online news. Proceedings of the American Society for Information Science and Technology, 47(1), 1-8. doi:10.1002/meet.14504701237 
Hup Xiao Hui and Ker Yuek Li / An Investigation Of Online News Consumption ....

Yadamsuren, B., \& Erdelez, S. (2011). Online news reading behavior: From habitual reading to stumbling upon news. Proceedings of the American Society for Information Science and Technology, 48(1), 1-10. doi:10.1002/meet.2011.14504801139 